\title{
Urgensi Penggunaan Instrumen Regeling dalam Pembentukan Kebijakan Pemerintah di Lingkungan Sekretariat Kabinet
}

\author{
Hermawan Susanto \\ Kedeputian Bidang Politik, Hukum, dan Keamanan, \\ Sekretariat Kabinet Republik Indonesia \\ hermawan@gmail.com
}

\begin{abstract}
This study aims to determine the urgency of using legal analysis instruments in the formation of government policies within the Cabinet Secretariat Republic of Indonesia. This research was analyzed by using a qualitative analysis method that uses a comparative approach. The results showed that the use of legal analysis instruments in the formation of government policies within the cabinet secretariat is very important given the strategic role of the cabbage secretariat as an institution whose function is to provide approval to the Minister of State Secretary for requests for permission to draft legislation and on the substance of the draft regulations legislation.
\end{abstract}

Keywords: Legal Analysis, Policy, Cabinet Secretariat, Over Regulation

\begin{abstract}
Abstrak
Penelitian ini bertujuan untuk mengetahui urgensi penggunaan instrumen analisis hukum dalam pembentukan kebijakan pemerintah di lingkungan Sekretariat Kabinet. Penelitian ini dianalisis dengan menggunakan metode analisis kualitatif yang menggunakan pendekatan perbandingan konsep (comparative approach). Hasil penelitian menunjukkan bahwa penggunaan instrumen analisis hukum dalam pembentukan kebijakan pemerintah di lingkungan sekretariat kabinet sangat penting dilakukan mengingat peran strategis sekretariat kabinet sebagai lembaga yang berfungsi untuk memberikan persetujuan kepada Menteri Sekretaris Negara atas permohonan izin prakarsa penyusunan rancangan peraturan perundangundangan dan atas substansi rancangan peraturan perundang-undangan.
\end{abstract}

Kata Kunci: Analisis Hukum, Kebijakan, Sekretariat Kabinet, Over Regulasi

\section{A. Pendahuluan}

Secara historis, asas pemerintahan berdasarkan hukum berasal dari pemikiran hukum abad ke-19 yang berjalan seiring dengan keberadaan negara hukum klasik atau negara hukum liberal dan dikuasai oleh berkembangnya pemikiran hukum legalistik-positivistik, terutama pengaruh aliran hukum 
legisme, yang menganggap hukum hanya apa yang tertulis dalam peraturan perundang-undangan. Secara normatif, prinsip bahwa setiap tindakan pemerintah harus berdasarkan peraturan perundang-undangan memang dianut di setiap negara hukum, namun dalam praktiknya penerapan prinsip ini berbedabeda antara satu negara dengan negara lain. Ada negara yang begitu ketat berpegang pada prinsip ini, namun ada pula negara yang tidak begitu ketat menerapkannya, artinya terhadap tindakan-tindakan pemerintah yang tidak begitu fundamental, penerapan prinsip tersebut dapat diabaikan.

Penyelenggaraan pemerintahan yang didasarkan pada asas legalitas, dalam praktiknya tidak memadai apalagi di tengah masyarakat yang memiliki tingkat dinamika yang tinggi. ${ }^{1}$ Hal ini karena hukum tertulis senantiasa mengandung kelemahan-kelemahan. Menurut Bagir Manan, hampir semua kalangan mengetahui dan memahami berbagai cacat bawaan (natural defect) dan cacat buatan (artificial defect) dari peraturan perundang-undangan sebagai suatu bentuk hukum tertulis. ${ }^{2}$ Cacat bawaan karena kelambanan pertumbuhan peraturan perundang-undangan dibandingkan dengan dinamika masyarakat, sedangkan cacat buatan karena masuk atau dimasukannya berbagai kebijakan atau tindakan yang mengganggu peraturan perundang-undangan sebagai sebuah sistem. Adanya kelemahan dalam hukum tertulis ini berarti pula adanya kelemahan dalam penerapan asas legalitas.

Dalam negara kesejahteraan (welfare state), asas legalitas saja tidak cukup untuk dapat berperan secara maksimal dalam melayani kepentingan masyarakat, freis ermessen kemudian muncul sebagai alternatif untuk megisi kekurangan dan kelemahan di dalam penerapan asas legalitas, namun penggunaan freis ermessen tidak boleh bertentangn dengan hukum yang berlaku baik hukum tertulis maupun hukum tidak tertulis, freis ermessen berlaku jika belum ada peraturan perundang-undangan yang mengatur tentang penyelesaian

${ }^{1}$ M. Azhar, "Relevansi Asas-Asas Umum Pemerintahan Yang Baik Dalam Sistem Penyelenggaraan Administrasi Negara," NOTARIUS, vol. 8, no. 2, pp. 274-286, Oct. 2015. https://doi.org/10.14710/nts.v8i2.10260.

${ }^{2}$ Bagir Manan, "Peranan Hukum Administrasi Negara Dalam Pembentukan Peraturan Perundangundangan", makalah disampaikan dalam Penataran Nasional Hukum Administrasi Negara, diselenggarakan Fakultas Hukum Universitas Hasanuddin, Ujung Pandang, 31 Agustus 1996. hlm. 1. 
in konkrito terhadap suatu masalah tertentu, peraturan perundang-undangan yang menjadi dasar berbuat aparat pemerintah memberikan kebebasan sepenuhnya, dan adanya delegasi perundang-undangan.

Dalam gagasan kontrak sosial yang diperkenalkan oleh Rousseau, yang juga sering dienal dengan sebutan kehendak umum (general will), kebijakan akan diterima oleh semua warga negara apabila kebijakan tersebut membagi beban dan keuntungan untuk semua warga negara secara adil.

Pembentukan kebijakan melalui mekanisme partisipasi akan menciptakan persamaan secara efektif. Dalam kebijakan berdasarkan general wiil, selalu diupayakan agar hak-hak dan kepentingan setiap warga negara dijamin dan terlindungi di dalamnya. Partisipasi dalam perumusan kebijakan perlu mempertimbangkan keterwakilan pemerintah (baca: campur tangan pemerintah) sebagai sebuah cara untuk melindungi segenap warga negara dan adanya good government. Penelitian singkat ini akan menjelaskan terkait dengan urgensi penggunaan instrumen regeling dalam pembentukan kebijakan pemerintah di lingkungan sekretariat kabinet.

\section{B. Pembahasan}

Pembahasan mengenai urgensi penggunaan instrumen regeling dalam pembentukan kebijakan pemerintah di lingkungan sekretariat kabinet dapat dijelaskan melalui tiga poin sub bab yaitu: evaluasi dalam pembentukan kebijakan, deregulasi, overregulasi, smarts regulation dan peran sekretariat kabinet dalam penentuan kebijakan pembentukan peraturan perundang-undangan.

\section{Evaluasi dalam Pembentukan Kebijakan}

Evaluasi dilakukan sebagai salah satu metode untuk memecahkan masalah dalam masyarakat. Permasalahan yang terjadi dalam masyarakat muncul karena kebijakan yang terkait dengan masalah tersebut tidak sanggup lagi mengatasi kasus yang terjadi. Rist C. Rist dalam Policy Evaluation (1995), menyampaikan salah satu bentuk penyelesaian masalah adalah dengan melakukan penelitian evaluasi kebijakan. Evaluasi kebijakan dapat digunakan sebagai sarana untuk menilai kebijakan tersebut berhasil atau gagal. ${ }^{3}$

\footnotetext{
${ }^{3}$ Ray C. Rist, 1995. Policy Evaluation, Great Britain: University Press, Cambridge, hal. 6.
} 
Pembuat kebijakan dalam mengidentifikasi masalah sosial memerlukan solusi, sehingga untuk mencapai solusi tersebut diperlukan informasi yang memadai, dimana informasi tersebut dapat diperoleh melalui sarana penelitian evaluasi kebijakan. Berdasarkan informasi dari penelitian evaluasi kebijakan, pembuat kebijakan dapat memberikan solusi atas masalah yang dihadapi masyarakat.

\section{Deregulasi}

Deregulasi secara etimologis berasal dari kata de dan regulation. Kata de yang berasal dari bahasa latin tersebut dapat diartikan sebagai penanggalan (removal), penurunan (degradation), pengurangan (reduction), atau kurang penting (disparagement). Sedangkan regulation yang berasal dari bahasa inggris sering diartikan sebagai pengaturan atau susunan. ${ }^{4}$ Secara simpel, maka deregulasi dapat dimaknai sebagai penanggalan, penurunan, atau pengurangan peraturan atau susunan. Atau secara lebih ringkas dapat dipahami sebagai penyederhanaan dan pengendalian penurunan dari fungsi pengaturan pemerintah.

Deregulasi menjadi penting manakala dalam praktik banyak terjadi peraturan perundang-undangan yang menghambat tujuan negara dalam mensejahterakan rakyat ${ }^{5}$. Dalam konteks saat ini, deregulasi banyak ditujukan untuk peraturan yang menghambat iklim investasi, menghambat laju pembangunan infrastruktur, dan secara umum kontraproduktif dengan usaha memajukan perekonomian bangsa. Penerapan deregulasi harus selaras, yang dimulai dari kebijakan pada tataran pusat, kemudian diikuti dengan deregulasi kebijakan di daerah.

\section{Over Regulasi}

\footnotetext{
${ }^{4}$ J.M. Otto, W.S.R. Stoter \& J. Arnscheidt, Using legislative theory to improve law and development projects, RegelMaat afl. 2004/4: 121- 135

5 Yusril Ihza Mahendra, "Bahan Penjelasan Mensesneg pada Rapat Kerja dengan Komisi II DPR RI tanggal 25 Januari 2006" (Disampaikan pada Rapat Kerja Menteri Sekretaris Negara - Komisi II DPR RI, Jakarta, 25 Januari 2006, dalam Akhmad Adi Purawan, Korupsi Legislasi Dalam Pembentukan Peraturan Perundang-Undangan, Jurnal RechtsVinding, Volume 3 Nomor 3, Desember 2014.
} 
Menteri PPN/Kepala Bappenas, Sofyan Djalil dalam berbagai forum perencanaan program pemerintah mengatakan bahwa jumlah regulasi di Indonesia sudah terlalu banyak (over regulasi). Hal tersebut menimbulkan masalah karena selain banyak peraturan perundang-undangan yang tidak efektif, banyak juga pejabat yang masih memiliki pola pikir bahwa keberadaan undangundang atau peraturan dapat menyelesaikan masalah. ${ }^{6}$

Presiden Joko Widodo, dalam Rapat Terbatas yang membahas Program Legislasi Nasional Prioritas Tahun 2016 memberikan arahan bahwa prinsip utama yang perlu direalisasikan dalam pengusulan rencana program penyusunan peraturan adalah tidak usah banyak mengeluarkan undang-undang. Namun yang terpenting adalah kualitas dari undang-undang tersebut. Dalam lima sampai dengan sepuluh tahun terakhir, ada sekitar 42.000 peraturan, mulai dari undang-undang sampai peraturan daerah. Presiden berharap, dalam jangka waktu setahun ke depan pemerintah direncanakan akan menderegulasi setengahnya, sehingga dapat meningkatkan pertumbuhan ekonomi. Masalah over regulasi di Indonesia dalam praktiknya memang telah mempersulit para investor asing dalam membuka usaha, sehingga pemerintah harus berkomitmen untuk menyederhanakan kerangka regulasi di tingkat pusat dan daerah.

Dalam World Economic Forum (2008) disampaikan bahwa over regulasi menjadi salah satu hambatan utama dalam membangun daya saing suatu negara. Apabila pemerintah, terutama daerah-daerah terus membuat regulasi (terutama yang negatif), maka akan berimbas ke citra bangsa. Untuk mencegah terus lahirnya peraturan di daerah yang bermasalah, perlu dilakukan beberapa tindakan, antara lain: peningkatan kualitas kinerja pemerintahan daerah, optimalkan fungsi legislatif daerah, sanksi tegas terhadap daerah yang tidak mengacu pada aturan pusat dalam membuat peraturan daerah.

Sebagai akibat gejala over regulasi, menurut Richard Susskind, timbul pula kecenderungan terjadinya alienasi hukum. Hukum makin lama makin terasing dari masyarakatnya. Dibutuhkan kelompok profesional yang mengkhususkan keahliannya di bidang hukum, yang terus menerus mengikuti perkembangan

${ }^{6}$ Lita Tyesta ALW, Aspek Penting Reformasi Regulasi (Perspektif Pembentukan Peraturan Perundangan), Orasi Ilmiah Disampaikan Pada Dies Natalis Ke-61 Fakultas Hukum Universitas Diponegoro, Semarang, 9 Januari 2018 
hukum dan bekerja profesional di bidang ini. Akan tetapi, para ahli hukum sendiri harus bekerja dengan lebih keras dan profesional. Para ahli hukum tidak saja dituntut untuk menguasai berbagai teori ilmu hukum tetapi juga memahami betul perkembangan aneka peraturan-peraturan yang berkembang cepat itu. Dunia pendidikan hukum dapat dipastikan akan gagal mempersiapkan sumber daya manusia yang berkualitas untuk bekerja di bidang hukum apabila orientasi kurikulum hanya memuat teori-teori yang dihasilkan dari masa lalu, tanpa mengaitkannya dengan peraturan-peraturan yang tumbuh cepat dalam kenyataan praktik.

\section{Filtering Regulasi}

Kecenderungan setiap instansi pemerintah adalah membuat peraturan perundang-undangan yang dapat memudahkan tugas dan fungsi serta memberikan kewenangan yang lebih bagi instansinya. Kecenderungan keinginan instansi pemerintah tersebut dalam praktiknya belum tentu sejalan dengan harapan atau general will masyarakat.

Bagi para legislatif drafting, sebenarnya terdapat banyak cara agar peraturan perundang-undangan yang diproses dapat disaring dengan baik. Dari banyak cara tersebut, telah berkembang di berbagai negara, dimana para legislatif draftingnya menyaring setiap usulan peraturan perundang-undangan dengan menggunakan suatu alat uji atau dengan metode assesment. Beberapa alat yang cukup populer digunakan untuk menyaring proses penyusunan peraturan perundang-undangan adalah metode ROCCIPI dan RIA.

Metode ROCCIPI diperkenalkan oleh Robert B. Seidman untuk pembentukan peraturan perundang-undangan yang baik, yaitu: rule (peraturan), opportunity (kesempatan), capacity (kemampuan), communication (komunikasi), interest (kepentingan), process (proses), dan ideology (ideologi). Metode tersebut dipakai untuk menganalisis proses penyusunan peraturan perundang-undangan dengan melibatkan pemegang peran (role ocupant) dan lembaga pelaksana (implementing agency).

Metode Regulatory Impact Assesment (RIA) adalah sebuah metode yang secara sistematis dan konsisten mengkaji pengaruh yang ditimbulkan oleh tindakan pemerintah, mengkomunikasikan informasi kepada para pengambil 
keputusan. ${ }^{7}$ RIA $^{8}$ pada dasarnya digunakan untuk menilai regulasi dalam hal: relevansi antara kebutuhan masyarakat dan sasaran kebijakan, kebutuhan terhadap intervensi pemerintah, efisiensi antara input dan output, efektifitas antara sasaran kebijakan dan hasil, keberlanjutan antara kebutuhan masyarakat, dan hasil sebelum diterapkannya atau dirubahnya suatu regulasi. ${ }^{9}$ Tahapan metode RIA yang dapat membantu pengambil kebijakan dalam merumuskan kebijakan adalah sebagai berikut: perumusan masalah, identifikasi tujuan kebijakan, identifikasi alternatif penyelesaian masalah, analisis biaya dan manfaat, komunikasi/konsultasi dengan stakeholders, penentuan alternatif kebijakan terbaik, dan perumusan strategi implementasi kebijakan.

\section{Smarts Regulation}

Dalam perkembangan teori kontemporer, terdapat tiga sifat kebijakan publik, yaitu rasional, inkremental, dan emergence. Kebijakan bersifat rasional mengacu kepada kemampuan dari pengambil kebijakan memilih alternatif kebijakan yang dianggap memberikan hasil yang paling optimal. Kebijakan inkremental memberikan kritikan terhadap sifat rasional dan menjelaskan bahwa kebijakan-kebijakan yang aktual jarang memenuhi persyaratan yang rasional. Kebijakan emergence atau penelusuran campuran (mixed-scanning) menawarkan suatu strategi penelusuran campuran sebagai alternatif dari rasional dan inkremental.

Pada masyarakat modern, terdapat peningkatan kompleksitas dinamika dan keragaman yang mengarah kepada kebutuhan sosial. Oleh sebab itu perlu dibangun suatu bentuk kolektivitas yang baru dalam bentuk pengaturan. Bentukbentuk pengaturan tersebut dipertimbangkan dalam karakteristik dinamika yang terjadi dalam masyarakat sebagai subsistem sosial. Perkembangan masyarakat modern yang telah terjadi, merupakan hasil interaksi kekuatan sosial dalam masyarakat.

\footnotetext{
${ }^{7}$ Biro Hukum Kementerian PPN/Bappenas, “Kajian Ringkas Pengembangan Dan Implementasi Metode Regulatory Impact Analysis (RIA) Untuk Menilai Kebijakan (Peraturan Dan Non Peraturan) Di Kementerian PPN/Bappenas", Jakarta: Kementerian PPN/Bappenas, 2011.

${ }^{8}$ OECD, "Regulatory Impact Analysis : Best Practices In OECD Countries", OECD 1997

9 Parker, David. "Regulatory Impact Assessment", Management Focus, Issue 24, Winter, Inggris: 2006, h. 4-7.
} 
Perkembangan tersebut sangat bergantung pada tindakan dari keragaman faktor sosial yang ada. Sehingga, sebelum diterapkan, kebijakan perlu dikomunikasikan kepada masyarakat dimana kebijakan akan diterapkan. Komunikasi yang efektif dalam melakukan penjaringan aspirasi, dapat menuntun masyarakat ke arah kebijakan yang dapat diterima di masyarakat. Interaksi pemerintah dengan masyarakat menjadi faktor kunci dalam perkembangan masyarakat modern. Selain penjaringan aspirasi sebelum penerapan kebijakan, juga ada faktor yang menyebabkan proses penerapan kebijakan terhambat, antara lain adalah: kebijakan bertentangan dengan sistem nilai, konsep ketidakpatuhan secara selektif (seperti adanya prioritas penegakan hukum), dan ketidakpastian hukum (seperti kurangnya equaliy before the law).

Kondisi umum yang dihadapi di negara berkembang adalah mereka harus menangani masalah sosial, politik, dan ekonomi yang sangat komplek dan menumpuk, dimana perkembangan atau perubahan di bidang tersebut tidak diimbangi dengan kecepatan pengaturan yang mendukung atau dibutuhkan. Kompleksitas yang dihadapi pemerintah dan para sarjana hukum di negara berkembang ditunjukkan oleh kenyataan, mereka sesungguhnya harus mengerjakan masalah-masalah yang di negara maju dilakukan secara bertahap, yaitu pembinaan bangsa, pembangunan ekonomi, dan kesejahteraan sosial. Namun yang membuat semakin runyam adalah, basis dari nilai-nilai ketigannya adalah berlainan.

Pembinaan bangsa menghendaki penyegaran kesadaran kolektif, dan pembangunan ekonomi menghendaki adanya keleluasaan bergerak setiap individunya. Adapun kesejahteraan sosial sebagai tahapan terakhir memerlukan pembatasan-pembatasan terhadap keleluasaan bergerak, yang diperlukan oleh pembangunan ekonomi tadi. Dalam negara berkembang, karena yang lebih dipikirkan adalah kesejahteraan rakyat, maka muncul masalah seperti pemerataan pendapatan, perlindungan terhadap ekonomi kecil dan lemah. Untuk kondisi Indonesia, kompleksitas tersebut dapat terlihat di mana arus upaya pembangunan ekonomi melalui deregulasi.

Ada beberapa hal yang harus dijawab sebelum sebuah peraturan dibuat, seperti urgensi atau perlunya peraturan tersebut dibuat, apakah ada cara lain 
untuk mengatur tanpa peraturan, dan apakah ada norma yang bukan peraturan yang bisa diadikan acuan agar tidak terjadi pelanggaran.

\section{Peran Sekretariat Kabinet dalam Penentuan Kebijakan Pembentukan Peraturan Perundang-undangan}

Sekretariat Kabinet menjalankan tugas dan fungsi berdasarkan Peraturan Presiden Nomor 25 Tahun 2015 tentang Sekretariat Kabinet. Salah satu fungsi Sekretariat Kabinet adalah: pemberian persetujuan kepada Menteri Sekretaris Negara atas permohonan izin prakarsa penyusunan rancangan peraturan perundang-undangan dan atas substansi rancangan peraturan perundangundangan (Pasal 3 huruf d).

Dalam rangka memberikan persetujuan atas permohonan izin prakarsa penyusunan dan atas substansi rancangan peraturan perundang-undangan, Sekretariat Kabinet akan terlibat dalam setiap tahapan dan forum pembahasan rancangan peraturan perundang-undangan. Dalam pembahasan, Sekretariat Kabinet akan mengkritisi substansi rancangan peraturan perundang-undangan, minimal dari sudut pandang nawacita, arahan-arahan Presiden, RPJMN, dan program prioritas pemerintahan. Sekretariat Kabinet mempunyai kewenangan untuk memberikan rekomendasi penghentian proses penyusunan rancangan peraturan perundang-undangan (yang belum disetujui Presiden) apabila substansinya dipandang tidak sesuai dengan hal-hal tersebut di atas.

\section{Simpulan}

Berdasarkan pada uraian tersebut maka urgensi penggunaan instrumen regeling dalam pembentukan kebijakan pemerintah di lingkungan sekretariat kabinet dilakukan melalui Evaluasi sebagai salah satu metode untuk memecahkan masalah dalam masyarakat. Permasalahan yang terjadi dalam masyarakat muncul karena kebijakan yang terkait dengan masalah tersebut tidak sanggup lagi mengatasi kasus yang terjadi. Deregulasi menjadi penting 
manakala dalam praktik banyak terjadi peraturan perundang-undangan yang menghambat tujuan negara dalam mensejahterakan rakyat.

Menteri PPN/Kepala Bappenas, Sofyan Djalil dalam berbagai forum perencanaan program pemerintah mengatakan bahwa jumlah regulasi di Indonesia sudah terlalu banyak (over regulasi). Hal tersebut menimbulkan masalah karena selain banyak peraturan perundang-undangan yang tidak efektif, banyak juga pejabat yang masih memiliki pola pikir bahwa keberadaan undang-undang atau peraturan dapat menyelesaikan masalah Beberapa alat yang cukup populer digunakan untuk menyaring proses penyusunan peraturan perundang-undangan adalah metode ROCCIPI dan RIA. Dalam perkembangan teori kontemporer, terdapat tiga sifat kebijakan publik, yaitu rasional, inkremental, dan emergence. Sekretariat Kabinet menjalankan tugas dan fungsi berdasarkan Peraturan Presiden Nomor 25 Tahun 2015 tentang Sekretariat Kabinet. Salah satu fungsi Sekretariat Kabinet adalah: pemberian persetujuan kepada Menteri Sekretaris Negara atas permohonan izin prakarsa penyusunan rancangan peraturan perundang-undangan dan atas substansi rancangan peraturan perundang-undangan (Pasal 3 huruf d).

\section{Daftar Pustaka}

Bagir Manan. 1966. Peranan Hukum Administrasi Negara Dalam Pembentukan Peraturan Perundang-undangan, makalah disampaikan dalam Penataran Nasional Hukum Administrasi Negara. Ujung Pandang : Fakultas Hukum Universitas Hasanuddin.

Biro Hukum Kementerian PPN/Bappenas, "Kajian Ringkas Pengembangan Dan Implementasi Metode Regulatory Impact Analysis (RIA) Untuk Menilai Kebijakan (Peraturan Dan Non Peraturan) Di Kementerian PPN/Bappenas", Jakarta: Kementerian PPN/Bappenas, 2011.

J.M. Otto, W.S.R. Stoter \& J. Arnscheidt, Using legislative theory to improve law and development projects, RegelMaat afl. 2004/4: 121- 135 
Lita Tyesta ALW, Aspek Penting Reformasi Regulasi (Perspektif Pembentukan Peraturan Perundangan), Orasi Ilmiah Disampaikan Pada Dies Natalis Ke-61 Fakultas Hukum Universitas Diponegoro, Semarang, 9 Januari 2018,

M. Azhar, "Relevansi Asas-Asas Umum Pemerintahan Yang Baik Dalam Sistem Penyelenggaraan Administrasi Negara," Notarius, Vol. 8, No. 2, pp. 274-286, Oct. 2015. https://doi.org/10.14710/nts.v8i2.10260.

OECD, "Regulatory Impact Analysis : Best Practices In OECD Countries", OECD 1997.

Parker, David. "Regulatory Impact Assessment", Management Focus, Issue 24, Winter, Inggris: 2006.

Peraturan Presiden Nomor 25 Tahun 2015 Tentang Sekretariat Kabinet.

Ray C. Rist. 1995. Policy Evaluation, Great Britain: University Press, Cambridge. 